March 2018

\title{
Cold agglutinins in peripheral blood with atypical cells with an owl-eye appearance in bone trephine
}

Ayesha Majeed Memon

Aga Khan University, ayesha.majeed@aku.edu

Farheen Karim

Aga khan University, farheen.mahar@aku.edu

Follow this and additional works at: https://ecommons.aku.edu/

pakistan_fhs_mc_pathol_microbiol

Part of the Hematology Commons, and the Pathology Commons

\section{Recommended Citation}

Memon, A. M., Karim, F. (2018). Cold agglutinins in peripheral blood with atypical cells with an owl-eye appearance in bone trephine. Journal of the College of Physicians and Surgeons Pakistan, 28(3), S58-S59.

Available at: https://ecommons.aku.edu/pakistan_fhs_mc_pathol_microbiol/705 


\title{
Cold Agglutinins in Peripheral Blood with Atypical Cells with an Owl-Eye Appearance in Bone Trephine
}

\author{
Ayesha Majeed Memon and Farheen Karim
}

\begin{abstract}
Autoimmune hemolytic anemia (AIHA) is a form of hemolytic anemia in which red cells lysis occurs due to presence of an autoantibody. Association of AlHA is well known with lymphoproliferative disorders, especially with non-Hodgkin's lymphoma. However, AlHA in association with Hodgkin's lymphoma is seen occasionally. Of the AlHA associated with Hodgkin's lymphoma, most are of warm type or mixed type. Cold AlHA, as seen in our case, is very rare in Hodgkin's lymphoma.
\end{abstract}

Key Words: Hodgkin's lymphoma. Autoimmune. Hemolytic anemia.

\section{INTRODUCTION}

Autoimmune hemolytic anemia (AIHA) is an acquired clinical condition which is characterised by the presence of autoantibodies that bind to the surface of circulating red blood cells, leading to hemolysis and shortened red blood cells survival. AlHA is very rarely reported in patient with Hodgkin's lymphoma, with an approximate incidence of around 0.2-4.2\%.1,2 Case reports and reviews have shown that AlHA occurs mostly at stages III and IV of Hodgkin's Lymphoma. ${ }^{3}$ Most of the cases reported show an association of Hodgkin's lymphoma with either warm or mixed type of AlHA. 4

Here, we report an unusual case of cold type AlHA in association with classic Hodgkin's lymphoma.

\section{CASE REPORT}

A 20-year female presented with a history of fever, weakness and weight loss for the last 2 months. General physical examination revealed pallor and cervical lymphadenopathy. Baseline complete blood counts showed hemoglobin: $102 \mathrm{~g} / \mathrm{L}$, HCT: $5.1 \%$, mean corpuscular volume (MCV): $91.1 \mathrm{fL}$, mean corpuscular hemoglobin $(\mathrm{MCH})$ : $182.1 \mathrm{pg}$, white blood cells (WBC): $4.5 \times 10^{9} / \mathrm{L}$, and platelets: $452 \times 10^{9} / \mathrm{L}$. Peripheral blood film showed numerous red cell agglutinates (Figures $1 \mathrm{~A}$ and 1B). White blood cells and platelets were normal on film. Considering the red cell indices and presence of agglutinates on peripheral blood film, the blood sample was incubated at $37^{\circ} \mathrm{C}$ water bath for about half hour.

Department of Pathology and Laboratory Medicine,

The Aga Khan University Hospital, Karachi.

Correspondence: Dr. Farheen Karim, Assistant Professor,

Section of Hematology and Transfusion Medicine,

Department of Pathology and Laboratory Medicine, The Aga

Khan University Hospital, Stadium Road, Karachi-74800.

E-mail:farheen.mahar@aku.edu

Received: June 23, 2017; Accepted: October 10, 2017.
Post-incubation sample was re-run and peripheral blood film reviewed. Red cell agglutinates disappeared after incubation (Figure 1C) and red cell indices were corrected as hemoglobin: $100 \mathrm{~g} / \mathrm{L}$ [Reference range: $113-145 \mathrm{~g} / \mathrm{L}$ ], HCT: $29.3 \%$ [Reference range: $35.4-42.0 \%$ ], MCV: $89.9 \mathrm{fL}$ [Reference range: $76-96 \mathrm{fL}$ ], $\mathrm{MCH}: 31.6 \mathrm{pg}$ [Reference range: $26-32 \mathrm{pg}$ ], WBC: $4.6 \times 10^{9} / \mathrm{L}$ [Reference range: 4-10 $\times 10^{9} / \mathrm{L}$ ] and platelets: $396 \times 109 / \mathrm{L}$ [Reference range: $150-400 \times 10^{9} / \mathrm{L}$ ]. Direct antiglobulin test [DAT] was positive $(3+)$. Monospecific DAT was positive for C3d

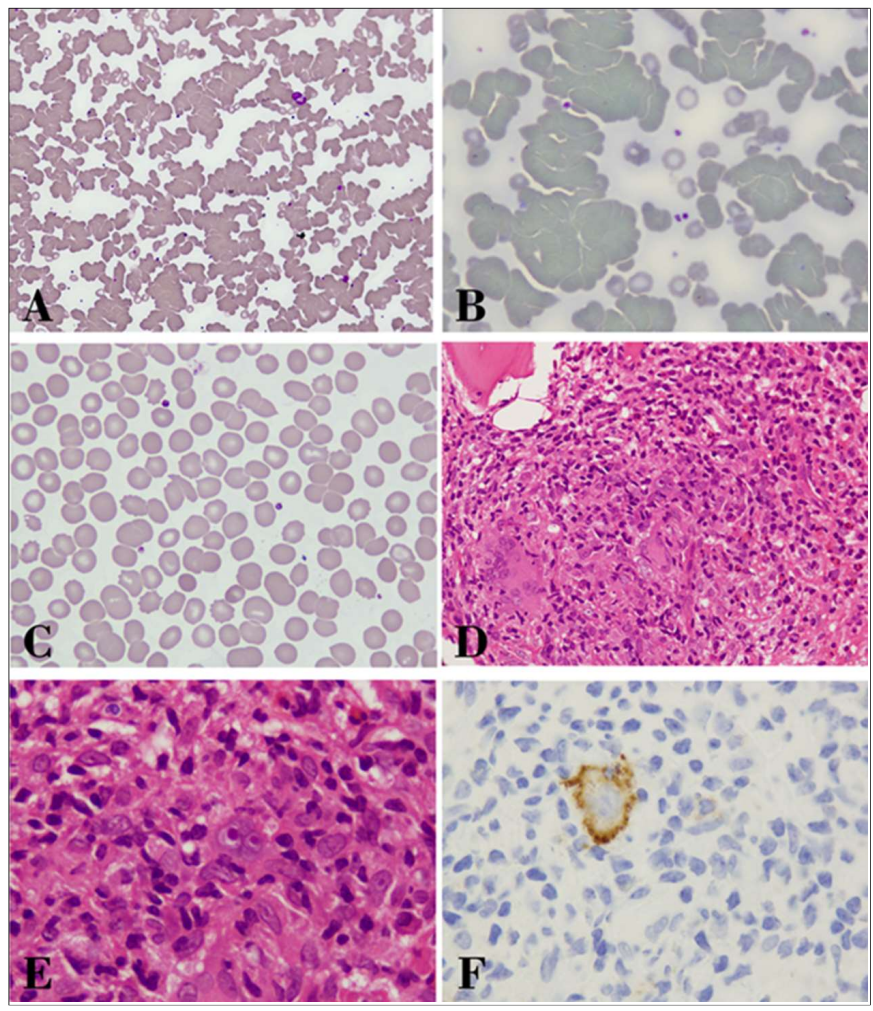

Figure 1: Peripheral blood film showing numerous red cell agglutinates [A and B]. Peripheral blood film after incubation at $37^{\circ} \mathrm{C}$ showing disappearance of agglutinates [C]. Bone trephine showing few granulomas with multinucleated giant cells [D]. Bone trephine with large mononuclear cells exhibiting owl's eye appearance [E]. CD 30 positive in large atypical mononuclear cells $[\mathrm{F}]$ 
$(3+)$ and negative for lgG. Cold agglutinin titre was not done in this patient. Other laboratory findings favouring hemolytic anemia included reticulocyte count of 0.04 proportion of red blood cells [Reference range: 0.0030.01 ], lactade dehydroguse (LDH) of $7.51 \mu \mathrm{Kat} / \mathrm{L}$ [Reference range: $3.47-6.31 \mu \mathrm{Kat} / \mathrm{L}$ ], and indirect bilirubin of $25.6 \mu \mathrm{mol} / \mathrm{L}$ [Reference range: 1.71-13.68 $\mu \mathrm{mol} / \mathrm{L}]$.

Bone marrow examination was done for workup of cold agglutinin disease. Bone marrow was dry tap. Bone trephine biopsy was a good length specimen showing effaced architecture. Cellular areas showed pleomorphic background comprising of mainly inflammatory cells including lymphocytes, plasma cells and eosinophils. Few granulomas were seen comprising of multinucleated giant cells (Figure 1D). Several interspersed large mononuclear cells were also noted exhibiting owl's eye appearance (Figure 1E). Few areas showed intense fibrosis. These large atypical mononuclear cells stained positive for CD 30 (Figure 1F) and negative for CD 20 and CD 3 on immunohistochemical stains. Findings were suggestive of bone marrow involvement with Hodgkin's lymphoma. For further confirmation, lymph node biopsy was advised. Cervical lymph node biopsy was consistent with the Classical Hodgkin's lymphoma. The patient was given 6 cycles of ABVD (doxorubicin, bleomycin, vinblastine, and dacarbazine) and responded to the treatment. DAT was performed after 6 months of treatment and was found to be negative.

\section{DISCUSSION}

The exact mechanism of AlHA in Hodgkin's lymphoma is not clear. It is hypothesised that the autoantibodies are produced by neoplastic cells and an immune regulatory phenomenon is involved. It is postulated that there might be an autoimmune mechanism at the initial stages of
Hodgkin's lymphoma in which autoantibodies are produced against the neoplastic lesion and erythrocytes as a paraneoplastic phenomenon. In addition, Hodgkin's lymphoma patients are known to have an impaired cellmediated immunity. This is due to a qualitative defect in $\mathrm{T}$ lymphocytes function and decreased number of cytotoxic $T$ cells. Reduction in cytotoxic $T$ cells may cause hyperactivation of $B$ cells leading to increase autoantibody production. 5,6

This case highlights the importance of diagnosing cold agglutinin disease. Cold agglutinin disease is not indolent, therefore, early diagnosis and identification of underlying cause is very important. While evaluating a case of hemolytic anemia, either warm or cold type, Hodgkin's lymphoma must be kept in mind.

\section{REFERENCES}

1. Levine AM, Thornton P, Forman SJ. Positive Coombs test in Hodgkin's disease: significance and implications. Blood 1980; 55:607-11.

2. Dimou M, Angelopoulou MK, Pangalis GA, Georgiou G, Kalpadakis C, Pappi V. Autoimmune hemolytic anemia and autoimmune thrombocytopenia at diagnosis and during followup of Hodgkin lymphoma. Leuk Lymphoma 2012; 53:1481-7.

3. Shah MB, Nanjapp V, Devaraj HS, Sindhu KS. Autoimmune hemolytic anaemia in Hodgkin's lymphoma. J Assoc Physicians India 2013; 61:492-4.

4. Siddiqui N, Aleem A. Autoimmune haemolytic anaemia preceding the diagnosis of Hodgkin's disease: a report of two cases and review of the literature. J Pak Med Assoc 2009; 59:316-9.

5. Gomes MM, Oliva T, Pinto A. Autoimmune hemolytic anemia and Hodgkin's disease: An unusual pediatric association. Case Rep Pediatr 2016; 2016:4598587.

6. Nikousefat Z, Javdani M, Hashemnia M, Haratyan A, Jalili A. Cold agglutinin disease; A laboratory challenge. Iran Red Crescent Med J 2015; $17: \mathrm{e} 18954$. 